Abstract P168 Table 1 Associations of age, gender, mode of referral and socioeconomic group with advanced stage of disease at diagnosis

\begin{tabular}{|c|c|c|c|c|}
\hline & $\begin{array}{c}\text { Late stage } \\
\text { disease (N) }\end{array}$ & $\begin{array}{l}\text { Early stage } \\
\text { disease (N) }\end{array}$ & OR (95\% CI) & $\mathbf{P}$ \\
\hline \multicolumn{5}{|c|}{ Age group (years) } \\
\hline$<60$ & 42 & 11 & Reference & 0.027 \\
\hline $60-69$ & 98 & 27 & $\begin{array}{l}0.95 \\
(0.43-2.09)\end{array}$ & \\
\hline $70-79$ & 104 & 51 & $\begin{array}{l}0.55 \\
(0.33-0.92)\end{array}$ & \\
\hline$>80$ & 81 & 46 & $\begin{array}{l}0.58 \\
(0.36-0.92)\end{array}$ & \\
\hline \multicolumn{5}{|l|}{ Gender } \\
\hline Male & 196 & 66 & $\begin{array}{l}1.59 \\
(1.06-2.38)\end{array}$ & 0.016 \\
\hline Female & 129 & 69 & Reference & \\
\hline \multicolumn{5}{|c|}{ Mode of referral } \\
\hline Emergency & 111 & 32 & $\begin{array}{l}1.92 \\
(1.19-3.10)\end{array}$ & 0.008 \\
\hline Community & 141 & 78 & Reference & \\
\hline \multicolumn{5}{|c|}{ Deprivation quintile } \\
\hline Most affluent & 67 & 25 & Reference & 0.72 \\
\hline 2 & 65 & 24 & $\begin{array}{l}1.01 \\
(0.52-1.95)\end{array}$ & \\
\hline 3 & 60 & 32 & $\begin{array}{l}0.70 \\
(0.41-1.19)\end{array}$ & \\
\hline 4 & 60 & 28 & $\begin{array}{l}0.90 \\
(0.53-1.51)\end{array}$ & \\
\hline Most deprived & 65 & 25 & $\begin{array}{l}1.11 \\
(0.67-1.87)\end{array}$ & \\
\hline
\end{tabular}

\section{P169 INVESTIGATING THE IMPACT OF SOCIAL DEPRIVATION IN LUNG CANCER PATIENTS IN NORTH GLASGOW}

doi:10.1136/thoraxjnl-2012-202678.230

${ }^{1} \mathrm{C}$ Tweed, ${ }^{2} \mathrm{~J}$ Farley, ${ }^{1} \mathrm{~J}$ Van Der Horst, ${ }^{3} \mathrm{~S}$ Bicknell, ${ }^{1} \mathrm{~J}$ Maclay, ${ }^{2} \mathrm{R}$ Milroy. ${ }^{1}$ Glasgow Royal Infirmary, Glasgow, UK; ${ }^{2}$ Stobhill Hospital, Glasgow, UK; ${ }^{3}$ Gartnavel General Hospital, Glasgow, UK

Introduction Lung cancer incidence and mortality rates are highest in the most deprived regions of Scotland. Glasgow has the highest incidence rate for lung cancer in Scotland at 92.8 people per 100, 000 population and the highest mortality rate at 75.4 people per 100, 000 population. The DEPCAT score is a well-validated index of deprivation unique to Scotland, based on post code. DEPCAT categorises deprivation into groups 1 (most affluent) to 7 (least affluent). We investigated social deprivation in North Glasgow and its relationship to lung cancer presentation, investigation, treatment, and mortality.

Methods All patients with lung cancer diagnosed in North Glasgow in 2009 and 2010 were prospectively recorded in a registry. We investigated prevalence, stage at presentation, performance status, attempts at tissue diagnosis and treatment administered with the DEPCAT score.

Results 1190 patients were diagnosed with lung cancer in the study period and clinical details were recorded at a multidisciplinary meeting. DEPCAT was available in more than $99 \%$ of patients. $61 \%$ of patients were from the most deprived categories ( 6 and 7 ).

Lung cancer was more prevalent in deprived areas (Table 1). Stage at presentation was not different based on social deprivation, but patients from deprived areas had a poorer performance status at presentation (PS 0-1 DEPCAT1-2: 58\% vs DEPCAT 6-7:40\%).

While there was no difference in whether tissue diagnosis was attempted, fewer patients from DEPCAT 6-7 underwent surgery or radical radiotherapy and more of this group were treated with best supportive care (Table 1).
There was a trend to better median survival in more affluent groups, but confidence intervals were overlapping.

Conclusions We found that the prevalence of lung cancer was higher in more deprived areas, in keeping with previous studies, and that these patients had a worse performance status at diagnosis despite similar stage of disease at presentation. Although there was no difference in pursuit of tissue diagnosis, fewer patients from more deprived areas underwent curative treatment. These differences in lung cancer diagnosis and management could be attributable to higher rates of co-morbidity in areas of lower socio-economic class.

\section{Abstract P169 Table 1}

\begin{tabular}{|c|c|c|c|}
\hline & $1-2$ & $3-5$ & $6-7$ \\
\hline$n$ & 108 & 356 & 718 \\
\hline Male sex, n (\%) & $56(51)$ & $180(51)$ & $357(50)$ \\
\hline Age, mean (SD) & $72(10)$ & $71(10)$ & $70(10)$ \\
\hline Prevalence (per 1000 patients) & 1.2 & 1.4 & 2.4 \\
\hline \multicolumn{4}{|l|}{ Stage at presentation, n (\%) } \\
\hline 1 & $20(19)$ & $45(13)$ & $100(14)$ \\
\hline 2 & $6(6)$ & $34(10)$ & $55(8)$ \\
\hline 3 & $33(31)$ & $98(28)$ & $214(30)$ \\
\hline 4 & $49(45)$ & $179(50)$ & $349(49)$ \\
\hline \multicolumn{4}{|l|}{ Performance status, n (\%) } \\
\hline 0 & $18(17)$ & $45(13)$ & $68(10)$ \\
\hline 1 & $44(41)$ & $119(33)$ & $216(30)$ \\
\hline 2 & $20(19)$ & $106(30)$ & $207(29)$ \\
\hline 3 & $12(11)$ & $48(14)$ & $125(17)$ \\
\hline 4 & $5(5)$ & $10(3)$ & $33(5)$ \\
\hline Not recorded & $9(8)$ & $28(8)$ & $69(10)$ \\
\hline Tissue diagnosis attempted, $\mathrm{n}(\%)$ & $92(85)$ & $298(84)$ & $597(83)$ \\
\hline \multicolumn{4}{|l|}{ Treatment, n (\%) } \\
\hline Best supportive care & $27(25)$ & $95(27)$ & $242(34)$ \\
\hline Palliative XRT & $31(29)$ & $87(24)$ & $164(23)$ \\
\hline Chemotherapy & $21(19)$ & $103(29)$ & $183(26)$ \\
\hline Surgery/radical radiotherapy & $29(27)$ & $71(20)$ & $129(18)$ \\
\hline Median survival, median days (95\%CI) & $\begin{array}{l}210 \\
(124-296)\end{array}$ & $\begin{array}{l}173 \\
(142-204)\end{array}$ & $\begin{array}{l}155 \\
(130-180)\end{array}$ \\
\hline
\end{tabular}

\section{P170 CHANGES IN THE EPIDEMIOLOGY OF LUNG CANCER IN A HOSPITAL IN LONDON, UK BETWEEN 2000 AND 2012}

doi:10.1136/thoraxjnl-2012-202678.231

K Ward, D Rao, SS Birring, R Lal, S Desai, S Ahmad, S Pomplun, J Kelly, I Atuchar, RD Barker. Kings College Hospital, Kings Health Partners, London, United Kingdom

Background Changes in the epidemiology of lung cancer could have important implications for treatment and prognosis. International studies have suggested adiminishing gap between the incidence of lung cancer in men and women and an increasing proportion of adenocarcinomas. ${ }^{1}$ We examined our own cohort of patients from a teaching hospital in south London UK to see whether these observations could be replicated.

Methods All patients with suspected intra-thoracic malignancy were logged in a bespoke database. Relevant parameters were recorded. Data items were defined according to the specifications of the Lucada dataset. Stage was coalesced into "Early" (1-2a), "locally advanced" (3a, 3b) and advanced (4). Analysis was restricted to the major cell types squamous cell, adenocarcinoma, small cell and 